\title{
Ekspresi Survivin Dan Potensinya Sebagai Biomarker Diagnostik Dan Prognostik Pada Neoplasma Tiroid
}

\author{
Survivin Expression And Its Potention As Diagnostic \\ And Prognostic Biomarker On Thyroid Neoplasm
}

\author{
Fathurrahman ${ }^{1}$, Tarsisia Truly Djimahit ${ }^{1}$, Upik A. \\ Miskad1, Dasril Dauci' \\ ${ }^{1}$ Department of Anatomical Pathology, Faculty of Medicine, Hasanuddin \\ University, Makassar \\ 2Department of Pediatric, Faculty of Medicine, Hasanuddin University, \\ Makassar
}

KATA KUNCI KEYWORDS

ABSTRAK
Tumor jinak dan ganas; folikel tiroid; antiapoptosis; survivin Benign and malignant tumors; thyroid follicles; antiapoptosis; survivin

Keganasan tiroid merupakan keganasan pada sistim endokrin tersering. Survivin merupakan anggota inhibitor of apoptosis protein (IAP) berperan dalam tumorigenesis melalui beberapa mekanisme yaitu menghambat apoptosis, mendorong progresi siklus sel, angiogenesis, invasi dan metastasis. Tujuan penelitian ini adalah untuk mengetahui perbedaan ekspresi survivin pada tumor jinak dan ganas asal sel folikuler tiroid dan antara tumor ganas dengan derajat differensiasi yang berbeda. Penelitian ini dilakukan dengan metode cross-sectional. Populasi penelitian adalah blok parafin sediaan lesi jinak dan ganas asal sel folikel tiroid yang tersiman di Instalasi Laboratorium Patologi Anatomi RS.Universitas Hasanuddin dan Sentra Diagnostik Patologia Makassar (SDPM) dari Januari 2016 - Desember 2017. Jumlah sampel 92 kasus terdiri dari 22 adenoma folikuler (AF) dan 70 karsinoma (21 karsinoma folikuler (KF), 37 karsinoma papiler (KP), 5 Karsinoma differensiasi buruk (KDB) dan 7 karsinoma anaplastik (KA)). Pada slide dari blok parafin yang memenuhi kriteria dilakukan pulasan imunohistokimia dengan antibodi poliklonal survivin, wild type. Perbedaan ekspresi survivin pada masing-masing kelompok diagnosis dianalisis dengan SPSS 23. Hasil penelitian menunjukkan perbedaan yang bermakna skor ekspresi survivin pada tumor jinak dengan ganas $(p=0,000)$. Antara KP papiler dengan $K D B$ buruk $(p=0,021)$ dan $K A(0,000)$ serta antara KF dengan $K A(p=0,002),(p<0,05)$. Hasil ini menunjukkan bahwa survivin berpotensi menjadi biomarker diagnostik antara AF dengan KF serta sebagai biomarker prognostik pada keganasan tiroid. 
ABSTRACT Thyroid malignancy is the most common malignancy in endocrine system. Survivin is a member of the inhibitor of apoptosis protein (IAP) plays a role in tumorigenesis through several mechanisms, namely inhibiting apoptosis, promoting cell cycle progression, angiogenesis, invasion and metastasis. The purpose of this study was to determine the differentiation of survivin expression in benign and malignant tumors of thyroid follicular cells derived and between malignant tumors with different degrees of differentiation. This study was carried out by crosssectional method. The study population was paraffin block preparations of benign and malignant lesions originating from thyroid follicular cells in the Anatomical Pathology Laboratory Installation of the Hospital. Hasanuddin University and Makassar Pathology Diagnostic Center (SDPM) from January 2016 to December 2017. The number of samples 92 cases consisted of 22 follicular adenomas and 70 carcinomas (21 follicular, 37 papillary, 5 poor differentiation and 7 anaplastic. In the slides of paraffin blocks that met the criteria performed immunohistochemical staining with polyclonal antibody survivin, wild type. Differences in survivin expression in each diagnosis group were analyzed by SPSS 23.The results showed significant differences in survivin expression scores on malignant benign tumors $(p=0,000)$. Between papillary carcinoma with poor differentiation carcinoma $(p=0.021)$ and anaplastic carcinoma (0.000) and between follicular carcinoma with anaplastic carcinoma $(p=0.002),(p<0.05)$. These results indicate that survivin has the potential to be a diagnostic biomarker between follicular adenomas with follicular carcinoma and as a prognostic biomarker in thyroid malignancy.

\section{PENDAHULUAN}

Keganasan tiroid merupakan keganasan pada sistim endokrin yang paling sering (Kim et al., 2012), (Waligórska-Stachura et al., 2014). Kanker tiroid mencakup $1 \%$ dari total kasus kanker di negara berkembang dan mengenai hampir seluruh kelompok usia, meskipun jarang pada anak-anak (Scopa 2004). Secara global pada tahun 2012, diperkirakan jumlah kematian akibat keganasanr tiroid mencapai 27.000 jiwa pada wanita dan 13.000 jiwa pada pria, dengan mortalitas rate pada wanita sekitar 0,6/100.000 dan 0,3/100.000 pada pria (La Vecchia et al., 2015). Publikasi data pasti khusus kasus keganasan tiroid di Indonesia hingga saat ini belum ada, namun data PERDATIN berdasarkan laporan dari RS.Kanker Darmais, periode 2011-213, keganasan tiroid konsisten di posisi ke 6, dengan kasus baru/kasus kematian berturut-turut 85/10 (2010), 99/4 (2011), 117/12 (2012), 147/9 (2013) (Kementrian Kesehatan RI Pusat Data dan Informasi Kesehatan, 2015).

Correspondence:

Fathurrahman, Department of Anatomical Pathology, Faculty of Medicine, Hasanuddin University, Makassar Email:fatrahmed@gmail.com 
Menurut data dari Laboratorium Patologi RS. UNHAS dan Sentra Diagnostik Patologia Makassar pada tahun 2014, didapatkan jumlah kasus neoplasma tiroid jinak dan ganas sebanyak 89 kasus, sedangkan pada tahun 2015 meningkat menjadi 123 kasus. Berdasarkan revisi buku WHO tentang klasifikasi endokrin tumor edisi 4, yang dipublikasi pada Juni 2017, keganasan asal sel folikel tiroid diklasifikasikan menjadi $\mathrm{KP}, \mathrm{KF}$, hurtle carcinoma, KDB, KA, dan karsinoma sel skuamous (King-yin Lam, 2017). Berbeda dengan karsinoma berdifferensiasi baik (KP dan folikuler) yang umumnya memililki prognosis yang baik, KA merupakan tumor pada manusia yang paling ganas dan agresif (Šelemetjev et al., 2011). KA bisa terjadi secara de novo atau sebagai transformasi dari karsinoma differensiasi baik, khususnya tipe papiler (King-yin Lam, 2017), (Šelemetjev et al., 2011). KDB memiliki pola histologis dan biologis yang berbeda dan terletak antara karsinoma differensiasi baik dan KA (Scopa 2004).

Beberapa molekul yang telah diketahui berperan dalam proses tumorigenesis tiroid diantaranya RTK, RAS, BRAF, MAP kinase pathway, yang dipandang terlibat dalam perkembangan karsinoma tiroid papiler. RAS merupakan onkogen pertama yang diasosiasikan dengan kanker tiroid, dan mutasi RAS djumpai pada neoplasma folikular benigna maupun maligna dan pada KP varian folikuler. Mutasi BRAF merupakan kelainan genetik yang paling sering pada karsinoma papiler, yaitu djumpai pada $83 \%$ kasus yang diteliti (Andrade et al., 2013). Survivin merupakan anggota terkecil dari inhibitor of apoptosis protein (IAP) family yang pertama kali diklon pada tahun
1997 (Mckenzie and Grossman, 2012). Survivin terlibat dalam tumorigenesis melalui beberapa mekanisme yaitu menghambat jalur apoptosis, pengaturan sitokenesis (mitosis) dan progresi siklus sel (Chen et al., 2016), angiogenesis (Sanhueza et al., 2015), berperan dalam invasi dan metastasis (Mehrotra et al., 2010), (Mckenzie and Grossman, 2012). Survivin terekspresi secara selektif pada sel-sel yang mengalami transformasi dan pada sebagian besar keganasan pada manusia, termasuk paru-paru, payudara, pankreas, kolon, sarkoma jaringan lunak, tumor otak, melanoma, neuroblastoma dan keganasan hematologik (Jaiswal, Goel and Mittal, 2015). Pada sel kanker, peningkatan survivin umumnya berkaitan dengan peningkatan indeks proliferatif, penurunan kadar apoptosis, resistensi terhadap kemoterapi, staging tumor lanjut, peningkatan angka rekurensi keganasan, outcome klinik yang buruk dan terbukti sebagai marker prognostik negatif yang independen (T.A. et al., 2017).

Terdapat beberapa penelitian mengenai ekspresi survivin pada keganasan tiroid. Survivin splice variant delta Ex3 mengalami overekspresi pada keganasan tiroid (Waligórska-Stachura et al., 2014). Survivin berhubungan dengan patogenesis KA dan dapat menjadi prediktor progresi penyakit (Kim et al., 2012). Survivin terekspresi tinggi pada KP dan memiliki peran dalam proses terjadinya KP proses metastase ke limfonodus dan staging kliniknya (Li et al., 2015). Berdasarkan penelusuran literatur, penelitian ekspresi survivin pada keganasan tiroid di Indonesia hingga saat ini belum pernah dilakukan, dengan demikian penelitian ini diharapkan dapat 
memberi sumbangsih ilmiah maupun aplikasi klinis dalam penatalaksanaan keganasan tiroid yang lebih baik ke depan. Penelitian ini secara umum bertujuan untuk mengetahui perbedaan ekspresi survivin pada keganasan tiroid dengan derajat differensiasi yang berbeda di Instalasi Patologi Anatomi RS. Universitas Hasanuddin dan Sentra Diagnostik patologia Makassar (SDPM), periode 1 Januari 2016 - 31 Desember 2017.

\section{CARA KERJA}

\begin{tabular}{llr}
\multicolumn{2}{c}{ Penelitian ini merupakan } \\
penelitian observasional analitik
\end{tabular} dengan pendekatan cross sectional. Sampel penelitian adalah arsip preparat HE dan blok parafin dari hasil tiroidektomi penderita dengan diagnosis $\mathrm{AF}, \mathrm{KF}, \mathrm{KP}, \mathrm{KDB}$ dan $\mathrm{KA}$, periode1 Januari 2016 - 31Desember 2017 yang diperiksa di Laboratorium Patologi Anatomik RS. Universitas Hasanuddin dan Sentra Diagnostik Patologia Makassar (SDPM) yang memenuhi kriteria inklusi dan eksklusi. Pengambilan sampel dilakukan dengan cara purposive/jugmental sampling, didapatkan 92 sampel penelitian yang terdiri dari $23 \mathrm{AF}, 22 \mathrm{KF}, 37 \mathrm{KP}, 5 \mathrm{KDB}$ dan 7 KA. Dilakukan review slide dan interpretasi ulang pada sediaan histologik oleh dua orang patologis dan hasilnya dikelompokkan menjadi AF, KF, KP, KDB dan KA. Pulasan imunohistokimia surviving menggunakan antibodi primer poliklonal survivin wild type, dengan pengenceran 1: 25 kali. (Santa Cruz, ED17:sc-6981, Biotechnology, Inc) untuk human dan tercat positif pada inti dan atau sitoplasma sel tumor.
Imunoreaktif surviving dilihat di area yang terpulas menggunakan pembesaran lemah (Obj.4x) terlebih dahulu untuk memilih daerah lesi. Selanjutnya pembesaran ditingkatkan (Obj.10x), dihitung persentase area yang terpulas dengan insentitas terkuat pada slide tersebut. Untuk melihat detail area yang terwarnai yang ditandai dengn warna coklat, pembesaran ditingkatkan ke Obj.40x. Ekspresi survivin dihitung secara semikuantitatif dengan menggabungkan tiga parameter yaitu intensitas (I), luas area yang terpulas (P) dan bagian sel yang terwarnai. Intensitas pulasan dibagi menjadi 4 kelompok, 0 : sel tumor tidak terwarnai (negatif), 1: sel tumor terwarnai lemah, 2: sel tumor terwarnai sedang, 3: sel tumor terwarnai kuat. Luas area yang terpulas $(\mathrm{P})$ dibagi menjadi 5 kelompok: 1: $<10 \%, 2: 10-25 \%, 3: 26-50 \%, 4: 51-75 \%$ dan $5>75 \%$, sedangkan bagian sel yang terwarnai dibagi menjadi 2 kelompok, 1 : terwarnai hanya di sitoplasma dan 2: terwarnai di sitoplasma dan inti.

Penilaiaan ekspresi survivin dengan menjumlahkan skor intensitas, luas daerah terpulas dan yang dibagi menjadi 5 kelompokyaitu negatif: skor 0-3, lemah: skor 4-5, sedang: skor 6-7, kuat: skor 8-9 dan sangat kuat: skor 10 . Analisis data menggunakan SPSS versi 23.0. Uji Kruskall Wallis digunakan untuk mengenai hubungan bermakna antara skor ekspresi survivin dengan diagnosis histopatologis yang dilanjutkan dengan analisis mengenai hubungan antara kelompok diagnosis dengan test Post Hoc, multiple comparison dengan metode Bonferoni. Nilai p dianggap bermakna bila $<0,05$. 


\section{HASIL}

Karakteristik umum penderita dan sampel pada penelitian ini disajikan dalam tabel 1 dan tabel 2 serta intensitas dan bagian sel yang terwarnai ditujukkan dalam gambar 1 berikut:

Tabel 1. Karakteristik penderita asal sampel penelitian $(\mathrm{n}=92)$

\begin{tabular}{cccc}
\hline $\begin{array}{c}\text { Karakteristik } \\
\text { Penderita }\end{array}$ & Keterangan & $\mathrm{n}$ & $\%$ \\
\hline \multirow{4}{*}{ Umur (tahun) } & $41-50$ & 32 & 43.5 \\
& $51-60$ & 16 & 17.4 \\
& $>60$ & 4 & 4.3 \\
jenis Kelamin & laki-laki & 13 & 14.1 \\
& Perempuan & 79 & 85.9 \\
\hline
\end{tabular}

Tabel 2. Karakteristik umum sampel

\begin{tabular}{|c|c|c|c|}
\hline \multicolumn{4}{|c|}{$(n=92)$} \\
\hline $\begin{array}{c}\text { Karakteristik } \\
\text { Sampel }\end{array}$ & Keterangan & $\mathrm{n}$ & $\%$ \\
\hline \multirow{5}{*}{$\begin{array}{l}\text { Diagnosis } \\
\text { Histopatologi }\end{array}$} & $\mathrm{AF}$ & 22 & 23.9 \\
\hline & KF & 21 & 22.8 \\
\hline & $\mathrm{KP}$ & 37 & 40.2 \\
\hline & KDB & 5 & 5.4 \\
\hline & KA & 7 & 7.6 \\
\hline \multirow{9}{*}{ Skor Survivin } & 0 & 6 & 6.5 \\
\hline & 3 & 10 & 10.9 \\
\hline & 4 & 7 & 7.6 \\
\hline & 5 & 7 & 7.6 \\
\hline & 6 & 11 & 12.0 \\
\hline & 7 & 12 & 13.0 \\
\hline & 8 & 18 & 19.6 \\
\hline & 9 & 16 & 17.4 \\
\hline & 10 & 5 & 5.4 \\
\hline \multirow{5}{*}{$\begin{array}{l}\text { Ekspresi } \\
\text { Survivin }\end{array}$} & Negatif & 16 & 17.4 \\
\hline & Lemah & 14 & 15.2 \\
\hline & Sedang & 23 & 25.0 \\
\hline & Kuat & 34 & 37.0 \\
\hline & $\begin{array}{c}\text { Sangat } \\
\text { Kuat }\end{array}$ & 5 & 5.4 \\
\hline
\end{tabular}

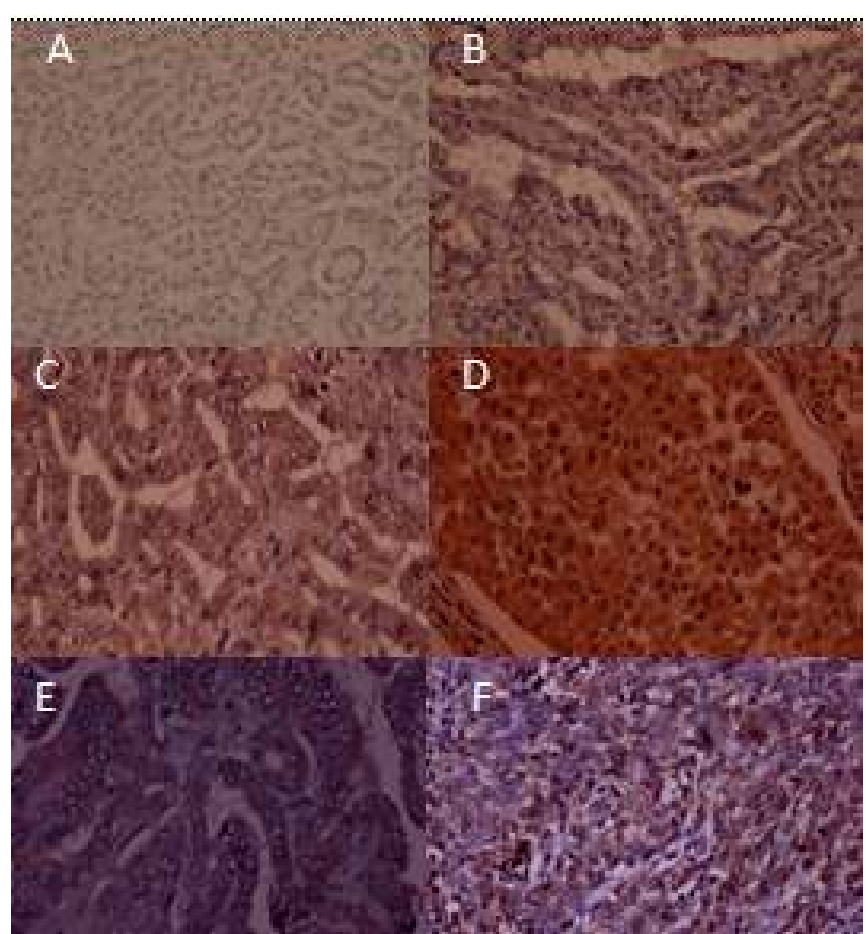

Gambar 1. Ekspresi survivin pada neoplasma tiroid. A.Survivin tidak terekspresi pada AF (Obj. 10x), B.

Survivin terkespresi dengan intensitas lemah, dan C. intensitas sedang pada KP (Obj. 40x). D. Survivin terekspresi dengan intensitas kuat pada KDB (Obj.

10x). E. Survivin terkspresi hanya di sitoplasma pada KP (Obj. 40x). F. Survivin terekspresi di sitoplasma dan inti pada KA (Obj. 40x).

Hubungan antara skor ekspresi survivin dan diagnosis histopatologi dianalisis dengan Uji Kruskal-Wallis, seperti ditunjukkan pada tabel 3.

Tabel 3. Perbedaan skor ekspresi survivin berdasarkan diagnosis histopatologi

\begin{tabular}{lccccc}
\hline \multirow{2}{*}{ SKOR } & \multicolumn{5}{c}{ DIAGNOSA } \\
& AF & KF & KP & KDB & KA \\
\hline Mean & 2.55 & 7.19 & 7.05 & 9.20 & 9.57 \\
Median & 3.00 & 8.00 & 7.00 & 9.00 & 10.00 \\
Minimum & 0 & 5 & 4 & 9 & 9 \\
Maksimun & 5 & 9 & 9 & 10 & 10 \\
\hline \multicolumn{5}{c}{ Uji Kruskal-Wallis $=63,186, \mathrm{df}=4, \mathrm{p}=$} \\
0,000 $(\mathrm{p}<0,05)$
\end{tabular}


Berdasarkan hasil Uji KruskalWallis didapatkan $p=0,000 \quad(p<0,001)$, yang berarti bahwa terdapat kelompok gambaran histopatologi yang memiliki perbedaan skor survivin yang bermakna. Setelah mengetahui adanya perbedaan bermakna antara skor ekspresi survivin dengan diagnonis histoptologis, maka perlu dilakukan analisis lebih lanjut mengenai hubungan antara kelompok diagnosis dengan test Post Hoc, multiple comparison dengan metode Bonferoni dan diperoleh hasil seperti pada tabel 4 .

Tabel 4. Hubungan Skor Ekspresi Survivin Antar Kelompok Diagnosis Histopatologis dengan Uji Bonferoni.

\begin{tabular}{lll}
\hline \multicolumn{1}{c}{ AF vs KF } & $p=0,000$ & $(p<0,05)$ \\
\hline AF vs KP & $p=0,000$ & $(p<0,05)$ \\
AF vs KDB & $p=0,000$ & $(p<0,05)$ \\
AF vs KA & $p=0,000$ & $(p<0,05)$ \\
KF vs KP & $p=1,000$ & $(p>0,05)$ \\
KF vs KDB & $p=0,055$ & $(p>0,05)$ \\
KF vs KA & $p=0,002$ & $(p<0,05)$ \\
KP vs KDB & $p=0,021$ & $(p<0,05)$ \\
KP vs KA & $p=0,000$ & $(p<0,05)$ \\
KDB vs KA & $p=1,000$ & $(p>0,05)$ \\
\hline
\end{tabular}

Pada penelitian ini, untuk ekspresi survivin antara $\mathrm{AF}, \mathrm{KF}, \mathrm{KP}$, membandingkan variabel nominal KDB dan KA maka dilakukan uji Chiantara dua atau lebih kelompok yang tidak berpasangan, yaitu frekuensi Square, seperti pada tabel 5:

Tabel 5. Analisis Hubungan Antara ekspresi Survivin dengan Diagnosis Histopatologis

\begin{tabular}{|c|c|c|c|c|c|c|c|c|c|c|c|c|}
\hline \multirow{3}{*}{ Diagnosa } & \multicolumn{10}{|c|}{ Ekspresi Survivin } & & \\
\hline & \multicolumn{2}{|c|}{ Negatif } & \multicolumn{2}{|c|}{ Lemah } & \multicolumn{2}{|c|}{ Sedang } & \multicolumn{2}{|c|}{ Kuat } & \multicolumn{2}{|c|}{$\begin{array}{c}\text { Sangat } \\
\text { Kuat }\end{array}$} & \multicolumn{2}{|c|}{ Total } \\
\hline & $\mathrm{n}$ & $\%$ & $\mathrm{n}$ & $\%$ & $\mathrm{n}$ & $\%$ & $\mathrm{n}$ & $\%$ & $\mathrm{n}$ & $\%$ & $\mathrm{n}$ & $\%$ \\
\hline $\mathrm{AF}$ & 16 & 72.7 & 6 & 27.3 & 0 & 0 & 0 & 0 & 0 & 0 & 22 & 100 \\
\hline $\mathrm{KF}$ & 0 & 0 & 2 & 9.5 & 8 & 38.1 & 11 & 52.4 & 0 & 0 & 21 & 100 \\
\hline $\mathrm{KP}$ & 0 & 0 & 6 & 16.2 & 15 & 40.5 & 16 & 43.2 & 0 & 0 & 37 & 100 \\
\hline $\mathrm{KDB}$ & 0 & 0 & 0 & 0 & 0 & 0 & 4 & 80 & 1 & 20 & 5 & 100 \\
\hline KA & 0 & 0 & 0 & 0 & 0 & 0 & 3 & 42.9 & 4 & 57.1 & 7 & 100 \\
\hline TOTAL & 16 & 17.4 & 14 & 15.2 & 23 & 25 & 34 & 37 & 5 & 5.4 & 92 & 100 \\
\hline
\end{tabular}

Chi Square $=122,010^{a}, \mathrm{df}=16, \mathrm{p}=0,00 \quad(\mathrm{p}<0,05)$ 


\section{PEMBAHASAN}

Tumor pada organ tiroid dapat bersifat jinak dan adapula yang ganas. Keganasan primer pada tiroid berasal dari sel-sel folikuler dengan tingkat differensiasi yang berbeda dari karsinoma differensiasi baik (KF dan KP), KDB dan KA (Scopa, 2004) (Katoh et al., 2015). Secara keseluruhan insiden keganasan tiroid cenderung meningkat begitupula dengan tingkat rekurensi yang mencapai $15-30 \%$ kasus. Dengan demikian menjadi penting untuk mengidentifikasi pasien yang berisiko tinggi mengalai rekurensi untuk menerapkan terapi yang lebih agresif disertai monitoring yang adekuat (Pannone et al., 2014). Survivin berperan pada tumorigenesis melalui beragam mekanisme, meliputi penghambatan jalur apoptosis, regulasi sitokinesis dan siklus sel, angiogenesis dan motilitas sel (invasi dan metastase) (Altieri, 2015). Pada tingkat subseluler, survivin berlokasi di beberapa tempat yaitu di sitoplasma, mitokondria dan nukleus (Mckenzie and Grossman, 2012), (Fortugno et al., 2017). Perbedaan lokasi survivin diyakini berhubungan erat dengan beragam fungsi selulernya. Penelitian menunjukkan survivin di nukleus memediasi fungsi survivin pada mitosis, sedangkan fraksi survivin di mitokondria dan sitoplasma berperan pada fungsi antiapoptosis.

Hasil-hasil penelitian dengan teknik immunohistokimia menunjukkan ekspresi survivin pada nukleus berkaitan dengan luaran klinik yang buruk (Joanna et al., 2012). Dibandingkan dengan penelitian mengenai ekspresi survivin pada breast dan kolorektal, data hasil penelitian ekspresi survivin pada kegnasan tiroid masih terbatas. Nilai diagnostik dan prognostiknya masih belum banyak dipahami (Pannone et al., 2014).

Dari tabel 1, diperoleh gambaran bahwa kasus tumor tiroid baik jinak maupun ganas terjadi pada rentang usia yang sangat lebar. Pada penelitian ini kasus terbanyak didapatkan rentang usia $<40$ tahun, 40 kasus $(43.5 \%)$, dan rentang usia dengan kasus terkecil adalah di atas 60 tahun yaitu 4 kasus (4.3\%). Hal ini sejalan dengan studi epidemiologis yang menyebutkan bahwa keganasan pada tiroid bisa mengenai semua usia, terutama pada dekade tiga sampai enam. (Katoh et al., 2015). Karakteristik sampel berdasarkan jenis kelamin (tabel 1), menunjukkan tumor tiroid lebih dominan mengenai wanita daripada laki-laki. Pada sampel penelitian ini, jumlah kasus pada pria berbanding wanita adalah 13: 79 (14,1\%:85,9\%). Hal ini selaras dengan data insidens dan mortalitas keganasan tiroid secara global dimana rasio kasus keganasan tiroid antara pria dan wanita adalah 1.9/100.000:6,1/100.000 (La Vecchia et al., 2015) (Scopa, 2004).

Pada tabel 2 mengenai karakteristik sampel berdasarkan diagnosis, didapatkan gambaran kelompok sampel terbanyak adalah kelompok KP yaitu 37 sampel (40.2\%) dan kelompok terkecil adalah KDB yaitu 5 sampel (5.4\%). Temuan ini sejalan dengan distribusi kasus keganasan tiroid secara global dimana KP mencakup 70-80\% dari seluruh keganasan tiroid, disusul KF (10-15\%) dan KA yang insidensnya sekitar 5\% (LiVolsi, 2011) (King-yin Lam, 2017). Pada penelitian ini, skor kumulatif ekspresi survivin pada sampel diperoleh dengan menjumlahkan parameter intensitas, persentase area yang terwarnai dan lokasi tempat survivin terekspresi seperti tampak 
pada tabel 2. Pada penelitian ini diperoleh gambaran bahwa pada kelompok $\mathrm{AF}, \mathrm{KP}$ dan $\mathrm{KF}$, survivin, terekspresi dengan intensitas dengan persentase yang bervariasi di sitoplasma. Sedangkan pada kelompok KDB dan KA, terdapat sampel yang menunjukkan survivin tereskpresi pada sitoplasma dan inti.

Pada penelitian ini di dapatkan bahwa jenis kelamin dan umur tidak memiliki hubungan yang bermakna dengan diagnosis histopatologis (variabel dependen) sehingga tidak dilakukan analisa hubungan antara ekspresi survivin (variabel independen) dengan jenis kelamin dan umur. Hubungan antara skor ekspresi dengan diagnosis histopatologi ditunjukkan dalam tabel 4 dengan menggunakan uji Kruskall Wallis. Hasil uji Kruskall Wallis menunjukkan adanya hubungan bermakna $(p<0,05)$ antara skor ekspresi surviving dengan diagnosis histopatologis. Untuk mengetahui hubungan skor ekspresi survivin antar kelompok diagnosis histopatologi dilakukan analisis lebih lanjut (post Hoc test) dalam hal ini uji Bonferroni. Dengan uji Bonferroni ditemukan bahwa skor ekspresi survivin antara kelompok diagnosis histopatologis tumor jinak (AF) berbeda bermakna dengan skor ekspresi survivin pada kelompok yang secara histopatologi didiagnosa sebagai tumor ganas $(\mathrm{KF}, \mathrm{KP}, \mathrm{KDB}$ dan $\mathrm{KA}$ dengan nilai $\mathrm{p}=0,000)$.

Pada analisis hubungan skor ekspresi survivin antara kelompok diagnosis tumor ganas diperoleh hasil yang berbeda-beda. Skor ekspresi survivin pada KP berbeda bermakna dengan skor ekspresi survivin pada kelompok $\operatorname{KDB}(p=0,021)$, dan dengan KA $(p=0,000)$. Skor ekspresi survivin pada karsinom folikuler tidak berbeda bermakna dengan skor ekspresi survivin pada KP $(p=1.000)$ dan pada KDB ( $p=0.055)$, sebaliknya berbeda bermakna dengan skor ekspresi survivin pada KA $(p=0,002)$. Terakhir, skor ekspresi survivin pada KDB tidak berbeda bermakna dengan skor ekspresi survivin pada KA $(p=1.000)$. Dari tabel 5, tampak bahwa survivin pada kelompok sampel AF umumya tidak terekspresi (negatif) yaitu mencakup $72,7 \%$ dan sisanya 27,3\% terekpresi positif lemah. Ekspresi survivin pada kelompok sampel KF dan KP semuanya positif dengan persentase terbesar masuk dalam kategori positif kuat yaitu sebesar 52,4\% dan 40,5\%. Ekspresi survivin pada kelompok sampel KDB dan KA, semuanya terekspresi pada rentang positif kuat dan positif sangat kuat. Sebagian besar (80\%) sampel KDB masuk kategori kuat dan sisanya (20\%) masuk kategori kuat. Sebaliknya pada KA, 57.1\% masuk kategori sangat kuat dan $42,9 \%$ masuk kategori kuat. Tidak terekspresinya survivin pada kelompok tumor jinak (AF) menunjukkan bahwa pada neoplasma jinak, proses apoptosis terutama diperankan oleh tumor suppressor gen seperti p53 tetap berlangsung.

Hal ini didukung dengan gambaran histopatologis yang menunjukkan tingkat differensiasi yang sangat minimal. Sejumlah penelitian menunjukkan p53 wild type, tapi tidak dengan p53 mutant type, dapat menekan ekspresi survivin pada level transkripsi (Chen et al., 2016). Perbedaan skor ekspresi survivin antara tumor jinak (AF) dan tumor ganas sejalan dengan hasil penelitian sebelumnya. Dengan menggunakan metode RT-PCR, Vandghanooni et al., menemukan bahwa survivin-DEx3 mengalami upregulasi secara signifikan pada tumor 
ganas tiroid (sekitar 10x lipat dibandingkan dengan jaringan tiroid normal (Babaei et al., 2011), (Pannone et al., 2014). Xiang et al,. dalam penelitiannya yang mengevaluasi eskpresi mRNA survivinpada lelevel ekspresi gen dengan quantitative RTPCR pada 98 kasus karsinoma tiroid menemukan bahwa tingkat ekspresi survivin berhubungan erat dengan aktivitas proliferasi sel, tipe patologis, metastase limfonodus dan metastase (Zhang et al., 2009). Chan et al., dalam penelitiannya dengan metode immunohistokimia dan RT-PCR menenemukan bahwa ekspresi survivin berbeda signifikan antara tumor ganas tiroid dengan struma tiroidea (Chen et al., 2012). Perbedaan skor ekspresi survivin antara AF dan KF sesuai dengan hasil penelitian sebelumnya. Haghpanah et al., dalam penelitiannya menunjukkan ekspresi survivin pada KF lebih tinggi secara signifikan dibandingkan ekspresi survivin pada AF $(p<0,05)$ dengan tingkat sensititifitas sebesar $81.8 \%$ dan $82.6 \%$ (Haghpanah, Shooshtarizadeh and Heshmat, 2006). Stachura et al., dalam dengan metode RT-PCR dan immunohistokimia meneliti ekspresi survivin dan splice variannya DEx3 dan 2B menemukan bahwa suvivin $(p=0,019)$, survivin DEx3 $(p=0,001), \quad$ survivin $2 B \quad(p=0,0149)$ terekspresi signifikan lebih tinggi pada tumor ganas dibandingkan lesi jinak tiroid (Waligórska-Stachura et al., 2017). Hasil yang berbeda didapatkan oleh Hye Jang et al., yang dalam penelitiannya didapatkan data survivin hanya terekspresi pada $<10 \%$ dari sampel penelitiannya dan tidak berbeda bermakna dengan kelompok AF (Jang, Jung and Min, 2015). Adanya perbedaan skor ekspresi survivin antara AF dengan KF menjadikan survivin berpotensi sebagai biomarker diagnostik pada kasus tumor tiroid bila diagnostik histopatologik sulit ditegakkan.

Dari tabel 3 Skor ekspresi survivin pada kelompok sampel dengan diagnosis tumor ganas berbanding terbalik dengan derajat differensiasinya, dimana semakin buruk tingkat differensiasinya maka skor ekspresi survivin makin meningkat. Hal ini mendukung teori dan hasil penelitian mengenai peran survivin dalam proses karsinogenesis yaitu sebagai inhibitor apoptotis, regulator mitosis, berperan dalam angiogenesis maupun pergerakan sel (Li et al., 1998), (Chen et al., 2016), (Colnaghi et al., 2006). Secara mikroskopis derajat differensiasi KP lebih jelek dari KF, namun secara klinis KF memiliki prognosis yang lebih jelek. Meskipun pada penelitian ini didapatkan skor ekspresi survivin pada KP dan folikuler tidak bermakna (p:1.000) namun terdapat kecenderungan skor ekspresi pada KF lebih tinggi dari KP. Hal ini bisa terjadi karena faktor polimorfisme gen yang terkait dalam proses karsinogenesis pada tiroid.

Salah satu gen yang diketahui mengalami mutasi pada 50\% kasus KF adalah gen RAS terutama isoform NRAS (Katoh et al., 2015), sedangkan RAS bersama signal aktivator dan transduser transkripsi 3, dan faktor anti apoptosis Wnt-2 diketahui berperan dalam up regulasi surviving (Mita et al., 2008). Sebaliknya pada KP, mutasi RAS jarang terjadi, mutasi yang umum terjadi adalah BRAV 600 dan PET. Pada penelitian in vivo, survivin merupakan mediator penting dalam proses motilitas sel dan invasi(Altieri, 2015), sehingga terdapat kemungkinan proses invasi kapsul dan atau vaskuler yang merupakan parameter diagnostik KF 
berkaitan dengan up regulasi survivin. Pada penelitian-penelitian sebelumnya $\mathrm{KP}$ dan KF sering digabung dalam entitas yang sama yaitu karsinoma tiroid differensasi baik (Pannone et al., 2014).

Meskipun skor ekspresi survivin antara KDB tidak berbeda bermakna dengan KA $(p=1.000)$, namun berdasarkan tabel 6, kedua kelompok diagnosis tersebut pada umumnya terekspresi kuat dan sangat kuat, serta masing-masing terdapat sampel dari keduanya yang terekspresi di inti. KDB dan KA, ada yang terjadi secara de novo, adapula pula sebagai hasil transformasi KP dan KF. KDB selanjutnya dapat mengalami transformasi menjadi KA. Mekanisme molekuler yang terjadi pada patogenesis KDB dan KA adalah mutasi P53, CTNBBI, dan PIK3CA (katoh 2015). Bila dihubungkan dengan survivin, p53 wild type, memiliki sifat antagonistik. Pada keadaan dimana p53 mengalami mutasi (p53 mutant type) seperti pada KDB dan KA, maka efek proapoptotik akan hilang dan sel-sel yang yang seharusnya diapoptosis akan tetap survive dan mengalami proliferasi. Hal ini dibuktikan dengan survivin yang terekspresi kuat pada sitoplasma (fungsi anti apoptosis) dan pada inti (terkait dengan mitosis/proliferasi sel).

Peran survivin dalam proses invasi dan metastase salah satunya diikaitkan dengan intraksi survivin dengan matriks metalloproteinase. Sejumlah data eksprimental menghubungkan ekspresi survivin dengan peningkatan produksi matriks metalloproteinase untuk mencerna matriks ekstraseluler, up regulasi 5 integrin yang berkombinasi dengan aktivasi Akt (Altieri, 2015). Mehrotra et al., dengan menggunakan line MDA-
MB-231 pada karsinoma mammae menunjukkan survivin yang berikatan dengan XIAP memediasi invasi dan metastase secara in vivo tanpa tergantung pada fungsi antiapoptosisnya (Mckenzie and Grossman, 2012)

Temuan ini sejalan dengan penelitian oleh Pannone et al., yang menemukan bahwa ekspresi protein survivin meningkat seiring dengan transisi ke differensiasi buruk. Mereka juga menemukan bahwa pada kelompok KDB dan KA, survivin terekspresi pada sitoplasma dan inti, dan terdapat hubungan erat antara ekspresi inti dengan kejadian KA (Pannone et al., 2014). Selemetjev et al., dalam penelitiannya dengan metode immunohistokimia melaporkan ekspresi survivin lebih kuat pada KA dibandingkan dengan KP (Šelemetjev et al., 2011). Temuan ini mengindikasikan bahwa survivin berperan dalam progresi keganasan tiroid, sehingga dapat dipertimbangkan menjadi biomarker prognostik. Pada penelitian ini informasi klinik yang diperoleh sangat terbatas, sehingga faktor-faktor yang kemungkinan berpengaruh terhadap variabel penelitian baik variabel dependen maupun independen tidak dapat dianalisis. Hal ini karena informasi klinik hanya berasal dari lembaran pengantar spesimen jaringan yang dijadikan sampel penelitian dan tidak memungkinkan untuk mengakses rekam medis pasien karena spesimen jaringan berasal dari banyak rumah sakit di dalam dan di luar kota. Informasi klinik tersebut dapat berupa ukuran tumor, soliter atau multiple, ada tidaknya ekstensi ke sekitar tiroid, ada tidaknya metastase ke kelenjar limfe dan metastase jauh serta staging tumor. Sampel pada penelitian ini berasal dari 
2 laboratorium patologi anatomi, dengan pesebaran sampel jaringan sangat variatif baik dari aspek daerah asal, etnis, agama maupun status ekonomi.

\section{SIMPULAN}

Hasil dari penelitian ini menunjukkan adanya hubungan yang bermakna antara skor survivin pada tumor jinak (AF) dengan tumor ganas (KF, KP, KDB dan KA). Pada kelompok tumor ganas ekspresi survivin berbanding terbalik dengan derajat differensiasi keganasan tiroid, semakin jelek differensiasinya maka ekspresi survivin lebih tinggi sehingga survivin berpotensi untuk digunakan sebagai biomarker prognostik. Survivin berpotensi untuk digunakan sebagai marker diagnostik untuk membedakan antara AF dengan KF pada kasus yang sulit dibedakan secara histopatologis.

\section{KEPUSTAKAAN}

Altieri DC 2015. 'Survivin - The inconvenient IAP', Seminars in Cell and Developmental Biology. Elsevier Ltd, 39, pp. 91-96. doi: 10.1016/j.semcdb.2014.12.007.

Andrade LJO, Melo PRS, Neto WA, Andrade CS, Margotto MAS, Franca LS, and Bittencourt AMV 2013. 'Molecular markers in Thyroid Cancer', Revista Argentina de Endocrinologia y Metabolismo, 50(73), pp. 84-98. Available at: http://www.raem.org.ar/numeros/20 13/2/84-98-Endo1-1-AndradeB.pdf\%5Cnhttp://www.embase.com Babaei E, Vandghanooni S, Montazeri V, Eskandani M, Halimi $M$ and Feizi MA 2011. 'Survivin-deltaEx3: A novel biomarker for diagnosis of papillary thyroid carcinoma', Journal of Cancer Research and Therapeutics, 7(3), p. 325. doi: 10.4103/0973-1482.87038.
Chen X, Duan N, Zhang C and Zhang W 2016. 'Survivin and tumorigenesis: Molecular mechanisms and therapeutic strategies', Journal of Cancer, 7(3), pp. 314-323. doi: 10.7150/jca.13332.

Chen Z, Liu N, Zhu G, Dralle H and Hoang$\mathrm{Vu} \mathrm{C}$ 2012. 'Targeting of the antiapoptotic gene survivin in human thyroid carcinoma', International Journal of Molecular Medicine, 30(3), pp. 465-472. doi: 10.3892/ijmm.2012.1046.

Colnaghi R, Connell CM, Barrett RMA and Wheatley SP 2006. 'Separating the antiapoptotic and mitotic roles of survivin', Journal of Biological Chemistry, 281(44), pp. 33450-33456. doi: 10.1074/jbc.C600164200.

Fortugno P, Nr W, Giodini A, Ds OC, Dcsurvivin A, Fortugno $P$, Dermopatico I, Wall NR, Fortugno P, Wall NR, Giodini A, Connor DSO and Plescia J 2017. 'Plescia J , Padgett KM , Tognin S , Marchisio PC , Survivin exists in immunochemically distinct subcellular pools and is involved in spindle microtubule function', (March 2002).

Haghpanah V, Shooshtarizadeh $\mathrm{P}$ and Heshmat, R 2006. 'Immunohistochemical Analysis of Survivin Expression in Thyroid Follicular Adenoma and Carcinoma', Applied Immunohistochemistry, 14(4), pp. 422-425. doi: 10.1097/01.pai.0000213100.88074.b8.

Jaiswal PK, Goel A and Mittal RD 2015. 'Survivin: A molecular biomarker in cancer', Indian Journal of Medical Research, 141(April), pp. 389-397. doi: 10.4103/0971-5916.159250.

Jang MH, Jung KC and Min HS 2015. 'SFN / 14-3-3 $\delta$ in Follicular Thyroid Carcinoma', Journal of Pathology and translational Medicine, pp. 112-117.

Joanna W, Anna J, Ryszard W, Wlodzimierz L, Maciej B, Agata C, Daria B, Violet S, Marek $\mathrm{R}$ and Waligórska-stachura J 2012. 'Survivin - prognostic tumor biomarker in human neoplasms review', Ginekol Pol, 83(7), pp. 537-540. 
Katoh H, Yamashita K, Enomoto $\mathrm{T}$ and Watanabe M 2015. 'Annals of Clinical Pathology Classification and General Considerations of Thyroid Cancer', Ann Clin Pathol, 3(1), pp. 1-9.

Kementrian Kesehatan RI Pusat Data dan Informasi Kesehatan 2015. 'Stop Kanker', infodatin-Kanker, p. hal 3.

Kim YA, Chang M, Park YJ and Kim JE 2012. 'Detection of survivin and COX-2 in thyroid carcinoma: Anaplastic carcinoma shows overexpression of nuclear survivin and low COX-2 expression', Korean Journal of Pathology, 46(1), pp. 55-60. doi: 10.4132/KoreanJPathol.2012.46.1.55.

King-yin Lam A 2017. 'Pathology of Endocrine Tumors Update: World Health Organization New Classification 2017-Other Thyroid Tumors', 22(4), pp. 209-216. doi: 10.1097/PCR.0000000000000183.

La Vecchia C, Malvezzi M, Bosetti C, Garavello W, Bertuccio P, Levi F and Negri E 2015. 'Thyroid cancer mortality and incidence: A global overview', International Journal of Cancer, 136(9), pp. 2187-2195. doi: 10.1002/ijc.29251.

Li F, Ambrosini G, Chu EY, Plescia J, Tognin S, Marchisio PC and Altieri DC 1998. 'Control of apoptosis and mitotic spindle checkpoint by survivin.', Nature, 396(6711), pp. 580-584. doi: $10.1038 / 25141$.

Li JY, Shi J, Sang JF, Yao YZ, Wang XC and $\mathrm{Su}$ L 2015. 'Role of survivin in the pathogenesis of papillary thyroid carcinoma', Genetics and Molecular Research, pp. 15102-15111. doi: 10.4238/2015.November.24.19.

Li Volsi VA 2011. 'Papillary thyroid carcinoma: an update', Modern Pathology. Nature Publishing Group, 24(S2), pp. S1-S9. doi: 10.1038/modpathol.2010.129.

Mckenzie JA and Grossman D 2012. 'Role of the apoptotic and mitotic regulator survivin in melanoma', Anticancer Research, 32(2), pp. 397-404.

Mehrotra S, Languino LR, Raskett CM, Mercurio AM, Dohi T and Altieri DC
2010. 'IAP Regulation of Metastasis', Cancer Cell. Elsevier Ltd, 17(1), pp. 5364. doi: 10.1016/j.ccr.2009.11.021.

Mita AC, Mita MM, Nawrocki ST and Giles FJ 2008. 'Survivin: Key regulator of mitosis and apoptosis and novel target for cancer therapeutics', Clinical Cancer Research, 14(16), pp. 5000-5005. doi: 10.1158/1078-0432.CCR-08-0746.

Pannone G, Santoro A, Pasquali D, Zamparese R, Mattoni M, Russo G, Landriscina $M$, Piscazzi A, Toti P, Cignarelli M, Lo Muzio L and Bufo P 2014. 'The Role of Survivin in Thyroid Tumors: Differences of Expression in Well-Differentiated, Non-WellDifferentiated, and Anaplastic Thyroid Cancers', Thyroid, 24(3), pp. 511-519. doi: 10.1089/thy.2013.0196.

Sanhueza C, Wehinger S, Castillo Bennett, J, Valenzuela M, Owen GI and Quest AFG 2015. 'The twisted survivin connection to angiogenesis', Molecular Cancer. Molecular Cancer, 14(1), p. 198. doi: 10.1186/s12943-015-0467-1.

Scopa CD 2004. 'Histopathology of thyroid tumors. An overview.', Hormones (Athens, Greece), 3(2), pp. 100-110. doi: 10.14310/horm.2002.11118.

Šelemetjev S, Cvejić D, Savin S, Paunović I and Tatić S 2011. 'Survivin in relation to Bcl-2, Bax and in Situ apoptotic cell death in anaplastic thyroid carcinoma', Archives of Biological Sciences, 63(4), pp. 955-964. doi: 10.2298/ABS1104955S.

T.A., W., D., D., I., N., J.C., R., S., M., P.E., V., K., R., S.A., T., W.T., K. and A., K. (2017) 'Survivin and XIAP - Two potential biological targets in follicular thyroid cancer', European Surgical Research, 58(February), pp. 15-18. doi: 10.1159/000463597.

Waligórska-Stachura J, Andrusiewicz M, Sawicka-Gutaj N, Biczysko M, Jankowska A, Kubiczak M, Czarnywojtek A, Wrotkowska E and Ruchała M 2014. 'Survivin delta Ex3 overexpression in thyroid malignancies', PLoS ONE. doi: 10.1371/journal.pone.0100534. 
Waligórska-Stachura J, Sawicka-Gutaj N, Zabel M, Andrusiewicz M, Gut P, Czarnywojtek A and Ruchała M 2017. 'Survivin DEx3 as a biomarker of thyroid cancers: A study at the mRNA and protein level', Oncology Letters, pp. 2437-2441. doi: 10.3892/ol.2017.5713.
Zhang HY, Meng X, Du ZX, Fang CQ, Liu GL, Wang HQ and Deng WW 2009. 'Significance of survivin, caspase-3, and VEGF expression in thyroid carcinoma', Clinical and Experimental Medicine, 9(3), pp. 207-213. doi: 10.1007/s10238-009-0031-7. 